\title{
Fertility and Inheritance of Variegated and Purple Foliage Across a Polyploid Series in Hypericum androsaemum $\mathbf{L}$.
}

\author{
Richard T. Olsen ${ }^{1}$ and Thomas G. Ranney ${ }^{2}$ \\ Department of Horticultural Science, Mountain Horticultural Crops Research and Extension Center, \\ North Carolina State University, Fletcher, NC 28732-9244
}

\author{
Dennis J. Werner ${ }^{3}$ \\ Department of Horticultural Science, North Carolina State University, Raleigh, NC 27695-7609
}

\begin{abstract}
Additional INDEX words. st. john's wort, tutsan, autotetraploid, oryzalin, invasive plants, pollen viability, ornamental plant breeding

Aвstract. Inheritance of two mutant foliage types, variegated and purple, was investigated for diploid, triploid, and tetraploid tutsan (Hypericum androsaemum). The fertility of progeny was evaluated by pollen viability tests and reciprocal crosses with diploids, triploids, and tetraploids and germinative capacity of seeds from successful crosses. Segregation ratios were determined for diploid crosses in reciprocal di-hybrid $F_{1}, F_{2}, B C P 1$, and $B C P 2$ families and selfed $F_{2} s$ with the parental phenotypes. $F_{2}$ tetraploids were derived from induced autotetraploid $F_{1} s$. Triploid segregation ratios were determined for crosses between tetraploid $F_{2} s$ and diploid $F_{1}$ s. Diploid di-hybrid crosses fit the expected $9: 3: 3: 1$ ratio for a single, simple recessive gene for both traits, with no evidence of linkage. A novel phenotype representing a combination of parental phenotypes was recovered. Data from backcrosses and selfing support the recessive model. Both traits behaved as expected at the triploid level; however, at the tetraploid level the number of variegated progeny increased, with segregation ratios falling between random chromosome and random chromatid assortment models. We propose the gene symbol var (variegated) and $p l$ (purple leaf) for the variegated and purple genes, respectively. Triploid pollen stained moderately well (41\%), but pollen germination was low (6\%). Triploid plants were highly infertile, demonstrating extremely low male fertility and no measurable female fertility (no viable seed production). The present research demonstrates the feasibility of breeding simultaneously for ornamental traits and non-invasiveness.
\end{abstract}

The genus Hypericum L. is a member of the large family Guttiferae (Clusiaceae, subfamily Hypericoideae, tribe Hypericeae) (Gustafsson et al., 2002) and contains about 370 species of herbs, shrubs, and trees distributed across the temperate zones and high elevations of the tropics (Mabberley, 1997; Robson, 1985). St. john's worts, as they are collectively known, have garnered much attention of late, with research focused on phytochemicals unique to the genus, including hypericins and hyperforins from common st. john's wort (H. perforatum L.) (Kirakosyan et al., 2004) and xanthones from tutsan $(H$. androsaemum) (Dias et al., 2000; Valentão et al., 2002). In addition to pharmacological value, the genus has contributed a number of important ornamental species including $H$. calcyinum L., H. forrestii (Chittenden) N. Robson, and $H$. androsaemum (Robson, 1985).

Received for publication 26 Apr. 2006. Accepted for publication 28 Sept. 2006. This research was funded, in part, by the North Carolina Agricultural Research Service (NCARS), Raleigh, NC 27695-7643; the North Carolina Association of Nurserymen, Inc., 969 Trinity Road, Raleigh, NC 27607; U.S. Dept. of Agriculture Floral and Nursery Research Initiative, Beltsville, MD 20705-2350; and J. Frank Schmidt Family Charitable Foundation, Boring, OR 97009. Use of trade names in this publication does not imply endorsement by NCARS of the products named nor criticism of similar ones not mentioned. Technical assistance of Thomas Eaker, Joel Mowrey, and Nathan Lynch, and staff of the Mountain Horticultural Crops Research and Extension Center is greatly appreciated. From a dissertation submitted by R.T.O. in partial fulfillment of the requirements for the $\mathrm{PhD}$ degree.

${ }^{1}$ Corresponding author. Current address: Floral and Nursery Plants Research Unit, USDA-ARS, US National Arboretum, 3501 New York Ave. NE, Washington, DC 20002; e-mail: Richard.Olsen@ars.usda.gov

2Professor.

${ }^{3}$ Professor, Director of the J.C. Raulston Arboretum.
Hypericum androsaemum $(2 n=2 x=40)$ is native from western Europe, through the Mediterranean and northern Africa, east into northern Iran (Robson, 1985). This semi-evergreen shrub grows less than $1 \mathrm{~m}$ in height and has an abundance of yellow, star-like flowers and fleshy red fruit that mature to a brown capsule. As a landscape plant, $H$. androsaemum and its hybrids with $H$. hircinum L. (H. xinodorum Miller), perform best in the cooler parts of U.S. Department of Agriculture hardiness zones 6 to 8. Various cultivars have been selected for the landscape and floriculture trade including yellow, variegated, and purple leaf forms. 'Mrs. Gladis Brabazon' and 'Glacier' are cultivars derived from $H$. androsaemum f. variegatum McClintock \& Nelson with heavily mottled leaves consisting of white, green, and light green patches (McClintock et al., 1986). 'Albury Purple' has purple blushed foliage and red-veined flowers; the origin of this cultivar is unknown.

Cultivation of $H$. androsaemum outside of its native range has led to naturalization in Europe, Australia, New Zealand, and Chile (Robson, 1985) and is a species of concern in the Pacific northwestern U.S. (D. Hinkley, personal communication). It is considered an invasive species in Australia, where biological control mechanisms are being studied (McLaren et al., 1997). Increasing awareness and concern about invasive plant species (Reichard and White, 2001) provide an opportunity for plant breeders to address this problem through the development of non-invasive cultivars. Bananas (Musa L.) and watermelons [Citrullus lanatus (Thunb.) Matsum. \& Nakai] are well-known examples of triploid plants displaying low fertility and seed development (Kihara, 1951; Ortiz and Vuylsteke, 1995). Few triploid ornamental plants have been developed, though the potential for using this approach to 
develop non-invasive cultivars is promising (Ranney, 2004). The triploid rose-of-sharon (Hibiscus syriacus L.) cultivars released by the U.S. National Arboretum shrub breeding program are notable exceptions (Egolf, 1970, 1981, 1986, 1988).

The objectives of this study were to investigate the mode of inheritance for two important ornamental traits, leaf variegation and purple foliage, across three ploidy levels [diploid $(2 x)$, triploid $(3 x)$, and tetraploid $(4 x)$ ] and to determine the fertility of progeny to assess the feasibility of developing non-invasive, triploid cultivars.

\section{Materials and Methods}

INHERITANCE STUDIES. Plants of $H$. androsaemum f. variegatum 'Glacier' (G) and 'Albury Purple' (AP) were maintained in the ornamental tree and shrub collection at the Mountain Horticultural Crops Research Station (MHCREC), Fletcher, N.C. Prior to beginning the study, open-pollinated seedlings from $\mathrm{G}$ and AP displayed their parental phenotypes, indicating that both traits were heritable. Plants for all crosses were grown in the greenhouse at MHCREC in 18.9-L containers in 3 pine bark: 1 peat (by volume) substrate amended with $2.8 \mathrm{~kg} \cdot \mathrm{m}^{-3}$ dolomitic limestone and $0.5 \mathrm{~kg} \cdot \mathrm{m}^{-3}$ micronutrients (Micromax; The Scotts Co., Marysville, Ohio), top-dressed with $50 \mathrm{~g}$ per container of $15 \mathrm{~N}-3.9 \mathrm{P}-10.0 \mathrm{~K}$ controlled-release fertilizer (15-9-12 Osmocote Plus 3-4 months at $70{ }^{\circ} \mathrm{C}$; The Scott's Co.) and watered by hand as needed. Reciprocal, di-hybrid $F_{1}$ and $F_{2}$ families were generated to investigate inheritance (Table 1). BCP1 and BCP2 families were produced as additional test crosses. $\mathrm{F}_{2 \mathrm{P} 1(2 x)}$ plants exhibiting the original parental phenotypes were selfed $\left(\mathrm{S}_{0}\right)$ to further verify genotypes. For all crosses, flowers were emasculated prior to anthesis, generally when the elongating floral bud was equal to subtending calyx lobes in length. Pollen was collected from recently dehisced anthers and either used fresh or dried overnight at $5{ }^{\circ} \mathrm{C}$ using indicator drierite (Drierite, Xenia, Ohio) and stored at $5{ }^{\circ} \mathrm{C}$ for use in later crosses. Pollen was applied daily to stigmas using small brushes, until stigmas turned brown after $\sim 10 \mathrm{~d}$. Fruit were collected when capsules turned from bright red to brown and allowed to dry at room temperature for $\sim 2 \mathrm{~d}$. Seeds were surface-sown onto a substrate of 1 peat : 1 vermiculite (by volume) in seedling flats $(58 \times 36 \times 6 \mathrm{~cm})$ and watered with intermittent mist ( $8 \mathrm{~s}$ every $6 \mathrm{~min}$ for $24 \mathrm{~h}$ ) until germination occurred in 1 to 4 weeks. Seedlings were transplanted into 40-cell trays with the same substrate and phenotypes were scored when seedlings had three sets of true leaves.

A subset of seedlings from $\mathrm{G} \times \mathrm{AP} \mathrm{F}_{1}\left[\mathrm{~F}_{1 \mathrm{P} 1(2 x)}\right]$ were treated with the mitotic-inhibiting herbicide oryzalin to induce tetraploidy

Table 1. Crosses between Hypericum androsaemum 'Glacier' (G) and 'Albury Purple' (AP) phenotypes and families produced.

\begin{tabular}{lcl}
\hline Cross & $\begin{array}{c}\text { Ploidy } \\
\text { of progeny }\end{array}$ & \multicolumn{1}{c}{ Families } \\
\hline $\mathrm{G} \times \mathrm{AP}$ & $2 x$ & $\mathrm{~F}_{1 \mathrm{P} 1(2 x)}, \mathrm{F}_{2 \mathrm{P} 1(2 x)^{\mathrm{z}}}$ \\
$\mathrm{AP} \times \mathrm{G}$ & $2 x$ & $\mathrm{~F}_{1 \mathrm{P} 2(2 x)}, \mathrm{F}_{2 \mathrm{P} 2(2 x)}$ \\
$\mathrm{G} \mathrm{X} \mathrm{F}_{1 \mathrm{P} 1(2 x)}$ & $2 x$ & $\mathrm{BCP} 1$ \\
${\mathrm{AP} \times \mathrm{F}_{1 \mathrm{P} 1(2 x)}}_{\mathrm{G} \mathrm{F}_{2 \mathrm{P} 1(2 x)} \text { selfed }}^{2 x}$ & $\mathrm{BCP} 2$ \\
$\mathrm{AP} \mathrm{F}_{2 \mathrm{P} 1(2 x)}$ selfed & $2 x$ & $\mathrm{~S}_{0}$ \\
$\mathrm{~F}_{1 \mathrm{P}(4 x)} \times \mathrm{F}_{1 \mathrm{P} 1(2 x)}$ & $2 x$ & $\mathrm{~S}_{0}$ \\
$\mathrm{~F}_{1 \mathrm{P} 1(4 x)}$ selfed & $3 x$ & $\mathrm{~F}_{2(3 x)}$ \\
\hline
\end{tabular}

$\overline{\text { zPloidy level in parentheses for each filial generation for clarity in de- }}$ scribing subsequent crosses.
$\left[\mathrm{F}_{1 \mathrm{P} 1(4 x)}\right]$. A total of 488 seedlings were selected from seedling flats after the first set of true leaves had emerged. Substrate was washed from roots and the entire seedling submerged in $150 \mu \mathrm{M}$ oryzalin [0.004\% Surflan; Dow AgroSciences, Indianapolis] for $24 \mathrm{~h}$. Following treatment, seedlings were washed under running water for $30 \mathrm{~min}$ and potted into 40-cell trays containing a 1 peat: 1 vermiculite (by volume) substrate and placed under intermittent mist ( 8 s every 6 min for $24 \mathrm{~h}$ ) for $3 \mathrm{~d}$, then grown under normal greenhouse conditions. Relative DNA content and associated ploidy levels were determined using a flow cytometer (PA-I Ploidy Analyzer; Partec GmbH, Münster, Germany). Nuclei isolation and staining [4',6-diamidino-2-phenylindole (DAPI)] followed the protocols provided by (Olsen et al., 2006). Induced tetraploids $\left[\mathrm{F}_{1 \mathrm{P} 1(4 x)}\right]$ were grown to flowering and selfed to investigate segregation of traits in an $\mathrm{F}_{2}$ tetraploid family $\left[\mathrm{F}_{2(4 x)}\right]$ or pollinized with diploid $\mathrm{F}_{1} \mathrm{~s}\left(\mathrm{~F}_{1 \mathrm{P} 1[2 x]}\right)$ to investigate segregation at the triploid level $\left[\mathrm{F}_{2(3 x)}\right]$ (Table 1). Samples of seedlings $(\mathrm{n}=25)$ from all crosses were analyzed using flow cytometry to confirm ploidy level of the progeny. Flow cytometry was also used to detect apomixis by analyzing ploidy levels of seeds from $\mathrm{F}_{1}$ crosses (Table 1). Seeds from sexual crosses will have a diploid embryo peak and a triploid endosperm peak, while seeds from apomictic (unreduced embryo sac) origin will have a diploid embryo peak and a tetraploid endosperm peak (Matzk et al., 2000). Seeds ( $\mathrm{n}=$ 25 per sample) were chopped using the same buffer and staining procedure as for foliage.

We hypothesized that variegated and purple leaf traits were two independent loci, both inherited in a simple Mendelian recessive manner. Segregation data were analyzed for departures from expected ratios using chi-square analysis on segregating families $\left[\mathrm{F}_{2 \mathrm{P} 1(2 \mathrm{x})}, \mathrm{F}_{2 \mathrm{P} 2(2 \mathrm{x})}, \mathrm{BCP} 1, \mathrm{BCP} 2, \mathrm{~F}_{2(3 \mathrm{x})}\right.$, and $\left.\mathrm{F}_{2(4 \mathrm{x})}\right]$. The chi-square test of independence for linkage was calculated for diploid $\mathrm{F}_{2} \mathrm{~S}$ $\left[\mathrm{F}_{2 \mathrm{P} 1(2 \mathrm{x})}\right.$ and $\left.\mathrm{F}_{2 \mathrm{P} 2(2 \mathrm{x})}\right]$. Crosses were conducted during the summers of 2003-05.

Fertility of Progeny. Reciprocal crosses between diploid $(2 x)$, triploid $(3 x)$, and tetraploid plants $(4 x)$ were made in 2005 to investigate male and female fertility as a function of ploidy level. Plants were grown in 18.9-L containers in the greenhouse using the same substrate and conditions described earlier and the same pollination techniques. Six plants per ploidy level were randomly sampled for pollen viability during the study. One flower per plant per ploidy level was harvested and anthers divided into two groups, with one group for pollen staining and the other for pollen germination tests. Pollen grains were stained in $40 \mu \mathrm{L}$ of $1 \%$ acetocarmine stain on a microscope slide. The slide was heated $3 \times$ over a hot-plate for $5 \mathrm{~s}$, sealed with valap (1 vaseline: 1 lanolin : 1 paraffin by weight), and incubated at room temperature $\left(23^{\circ} \mathrm{C}\right)$ for $5 \mathrm{~h}$. Stained, well-formed pollen grains were scored as viable. Pollen germination was performed in 5-mL petri dishes containing Brewbaker-Kwack media supplemented with 5\% sucrose and solidified with 2\% agarose (Marquard, 1992). Pollen grains with pollen tubes greater than one-half the diameter of the pollen grain after $5 \mathrm{~h}$ were scored as germinated. Pollen staining and germination were observed using a compound light microscope (Micromaster; Fisher Scientific, Pittsburgh) under $\times 100$ and $\times 400$ magnifications. For each replicate $\geq 100$ pollen grains were scored. The experiment was a completely randomized design with three treatments (ploidy levels) and six replicates $(n=6)$.

Crosses among the three ploidy levels resulted in nine factorial treatment combinations. The experiment was a completely randomized design with five single-plant replicates $(n=5)$ per 
cross with 10 flowers (subsamples) pollinated per plant. Fruit from successful crosses matured $\sim 40 \mathrm{~d}$ after pollination. Fruit were harvested, dried, and seeds separated and stored in sealed vials at $5{ }^{\circ} \mathrm{C}$ until used for germination studies. Total number of fruit per cross, percentage of fruit set, and average seeds per fruit were recorded.

Germinative capacity of seeds harvested from successful crosses was determined using in vitro germination studies. Two germination blotters (SDB3.5; Anchor Paper Co., St. Paul, Minn.) soaked with $100 \mu \mathrm{M}$ gibberellic acid $\left(\mathrm{GA}_{4+7}\right)\left(21 \mathrm{~g} \cdot \mathrm{L}^{-1}\right.$ Provide; Valent Biosciences, Walnut Creek, Calif.) were placed in petri dishes $(100 \times 15 \mathrm{~mm})$. A sample of 50 seeds per fruit, or all seeds available when $<50$, were sown per petri dish. Petri dishes were sealed with parafilm and placed in a growth chamber maintained at $22{ }^{\circ} \mathrm{C}, 16 \mathrm{~h}$ day $/ 8 \mathrm{~h}$ night period, and $42 \mu \mathrm{mol} \cdot \mathrm{s}^{-1} \cdot \mathrm{m}^{-2}$ photosynthetically active radiation $(P A R)$ provided by fluorescent lights. After 8 weeks, seeds with emergent radicles were scored as germinated.

Data from pollen, crossing, and germination studies were analyzed using analysis of variance (PROC GLM; SAS version 8.02, SAS Institute Inc., Cary, N.C.) and means compared using Fisher's protected least significant difference (LSD) at $\alpha=0.05$.

\section{Results}

INHERITANCE STUDIES. Reciprocal $\mathrm{F}_{1}$ crosses yielded progeny that were all non-variegated and green, with the exception of three variegated seedlings $\left[\mathrm{F}_{1 \mathrm{P} 1(2 x)}\right]$ and one purple seedling $\left[\mathrm{F}_{1 \mathrm{P} 2(2 x)}\right]$, which were attributed to accidental self-pollination (Table 2). No evidence for apomixis was observed from flow cytometry analysis of $F_{1}$ seed; thus, all progeny appeared to be the result of sexual crosses (data not shown). Segregation ratios for the diploid $\mathrm{F}_{2}$ families $\left[\mathrm{F}_{2 \mathrm{P} 1(2 x)}\right.$ and $\left.\mathrm{F}_{2 \mathrm{P} 2(2 x)}\right]$ fit the expected $9: 3: 3: 1$ ratio, supporting the hypothesis of simple recessive inheritance for both traits. The chi-square test for independence of linkage $\left[\chi^{2}=1.75\right.$, $P=0.19$ and $\chi^{2}=0.02, P=0.89$ for $\mathrm{F}_{2 \mathrm{P} 1(2 x)}$ and $\mathrm{F}_{2 \mathrm{P} 2(2 x)}$, respectively] suggests no evidence for linkage between the variegated and purple loci. Furthermore, recovery of variegated and purple seedlings in both $\mathrm{F}_{2}$ populations $\left[\mathrm{F}_{2 \mathrm{P} 1(2 x)}\right.$ and $\left.\mathrm{F}_{2 \mathrm{P} 2(2 x)}\right]$ effectively rules out strict maternal inheritance. Segregation ratios for BCP1 fit the expected $1: 1$ ratio of non-variegated: variegated phenotypes (Table 2). However, in BCP2 a few spontaneous variegated green and variegated purple seedlings were observed which can not be explained by accidental self-pollination or pollen contamination. These seedlings were scored as either non-variegated or purple for chi-square analysis; however, due to the presence of more purple seedlings than expected (221 observed vs. 199.5 expected) we still had a poor fit. $\mathrm{F}_{2}$ plants $\left[\mathrm{F}_{2 \mathrm{P} 1(2 x)}\right]$ exhibiting the original $\mathrm{G}$ or AP phenotype when selfed $\left(\mathrm{S}_{0}\right)$ yielded all variegated or all purple progeny, respectively (Table 2 ).

Induction of autotetraploids $\left[\mathrm{F}_{1 \mathrm{P} 1(4 x)}\right]$ from $\mathrm{F}_{1 \mathrm{Pl}(2 x)}$ seedlings was successful. Of 488 seedlings treated, 16.2\% survived (79 of 488) the treatment. Of those that survived, 39.2\% remained diploid, $45.6 \%$ were mixoploids, and $15.2 \%$ were non-chimeric tetraploids. Autotetraploids grew slowly at first, but otherwise were similar to their diploid counterparts. Triploid $\left[\mathrm{F}_{2(3 x)}\right]$ and tetraploid $\left[\mathrm{F}_{2(4 x)}\right]$ seedlings from crosses with autotetraploids grew normally, except tetraploid AP phenotypes which tended to be poor growers.

Triploid $\mathrm{F}_{2}\left[\mathrm{~F}_{2(3 x)}\right]$ progeny fit the expected $121: 11: 11: 1 \mathrm{seg}$ regation ratio (Table 2 ). However, at the tetraploid level $\left[\mathrm{F}_{2(4 x)}\right]$ we observed more than three times as many variegated phenotypes than expected (76 observed vs. 21.6 expected) and thus had a poor fit to the expected $1225: 35: 35: 1$ segregation ratio for tetrasomic inheritance at the tetraploid level. We analyzed inheritance for each locus separately for random chromosome and chromatid assortment (at 50\% recombination), as well as for selective pairing at the tetraploid level to elucidate possible mechanisms for departure from our expected ratio for the variegated trait. Random chromosome assortment for one recessive gene at the tetraploid level would segregrate 35 wild-type: 1 mutant. For the purple locus, there was no reason to reject the assumption of random chromosome assortment at the tetraploid level $\left(\chi^{2}=0.028, P=\right.$ $0.867)$; however, the variegated locus did not fit $\left(\chi^{2}=138.9, P<\right.$ $0.001)$. For random chromatid assortment at $50 \%$ recombination we would expect 20.8 wild-type : 1 mutant, and the variegated locus failed to fit $\left(\chi^{2}=46.4, P<0.001\right)$. Assuming preferential or selective pairing, we would expect 15 wild-type $: 1$ mutant, and

Table 2. Segregation for foliage traits in Hypericum androsaemum across ploidy levels in families derived from 'Glacier' (G) and 'Albury Purple' (AP).

\begin{tabular}{|c|c|c|c|c|c|c|c|c|}
\hline \multirow[b]{2}{*}{ Cross } & \multirow[b]{2}{*}{ Families } & \multicolumn{4}{|c|}{ Progeny (no. seedlings) ${ }^{z}$} & \multirow[b]{2}{*}{$\begin{array}{l}\text { Expected } \\
\text { ratio }\end{array}$} & \multirow[b]{2}{*}{$\chi^{2}$} & \multirow[b]{2}{*}{$P$} \\
\hline & & $\begin{array}{l}+/- \\
+/-\end{array}$ & $\begin{array}{c}\text { var/var } \\
+/-\end{array}$ & $\begin{array}{l}+/- \\
\mathrm{pl} / \mathrm{pl}\end{array}$ & $\begin{array}{c}\text { var/var } \\
\mathrm{pl} / \mathrm{pl}\end{array}$ & & & \\
\hline$\overline{\mathrm{G} \times \mathrm{AP}}$ & $\mathrm{F}_{1 \mathrm{P} 1(2 x)^{\mathrm{y}}}$ & 130 & $3^{x}$ & 0 & 0 & $1: 0: 0: 0$ & 0.00 & 1.00 \\
\hline $\mathrm{AP} \times \mathrm{G}$ & $\mathrm{F}_{1 \mathrm{P} 2(2 x)}$ & 162 & 0 & $1^{x}$ & 0 & $1: 0: 0: 0$ & 0.00 & 1.00 \\
\hline $\mathrm{G} \times \mathrm{AP}$ & $\mathrm{F}_{2 \mathrm{P} 1(2 x)}$ & 218 & 71 & 88 & 20 & $9: 3: 3: 1$ & 3.69 & 0.30 \\
\hline $\mathrm{AP} \times \mathrm{G}$ & $\mathrm{F}_{2 \mathrm{P} 2(2 x)}$ & 214 & 77 & 81 & 28 & $9: 3: 3: 1$ & 1.43 & 0.70 \\
\hline $\mathrm{G} \times \mathrm{F}_{1 \mathrm{P} 1(2 x)}$ & BCP1 & 200 & 196 & 0 & 0 & $1: 1: 0: 0$ & 0.04 & 0.84 \\
\hline $\mathrm{AP} \times \mathrm{F}_{1 \mathrm{P} 1(2 x)}$ & $\mathrm{BCP} 2$ & 178 & $4^{w}$ & 221 & $3^{w}$ & $1: 0: 1: 0$ & 4.63 & 0.03 \\
\hline G selfed & $\mathrm{S}_{0}$ & 0 & 200 & 0 & 0 & $0: 1: 0: 0$ & 0.00 & 1.00 \\
\hline AP selfed & $\mathrm{S}_{0}$ & 0 & 0 & 200 & 0 & $0: 0: 1: 0$ & 0.00 & 1.00 \\
\hline $\mathrm{F}_{1 \mathrm{P} 1(4 x)} \times \mathrm{F}_{1 \mathrm{P} 1(2 x)}$ & $\mathrm{F}_{2(3 x)}$ & 573 & 46 & 49 & 3 & $121: 11: 11: 1$ & 1.38 & 0.71 \\
\hline $\mathrm{F}_{1 \mathrm{P} 1(4 x)}$ selfed & $\mathrm{F}_{2(4 x)}$ & 701 & 76 & 22 & 1 & $1225: 35: 35: 1$ & 141.20 & $<0.001$ \\
\hline
\end{tabular}

${ }^{2}$ Number of progeny for each phenotypic class $(+/-+/-=$ non-variegated, green; $v a r / v a r+/-=$ variegated, green; $+/-p l / p l=$ non-variegated, purple; var/var $p l / p l=$ variegated, purple).

yPloidy level in parentheses for each filial generation for clarity in describing subsequent crosses.

xUnexpected and inconsistent with proposed simple recessive model, due to possible accidental self-pollination. Data not used in chi-square calculations.

wUnexpected and unexplained variegation, which can not be explained by self- or cross-pollen contamination. These seedlings were scored as either non-variegated or purple for chi-square calculations. 
again, the variegated locus failed to fit $\left(\chi^{2}=15.6, P<0.001\right)$.

If above the diploid level the variegated trait behaves quantitatively, the frequency of variegated progeny in both triploid and tetraploid crosses would increase, and classes of variegation from weak (duplex) to strong variegation (quadriplex) may be discerned. At the tetraploid level we would then expect 3 variegated: 1 non-variegated progeny; however, the variegated locus did not fit this either $\left(\chi^{2}=100.9, P<0.001\right)$.

Fertility OF Progeny. Ploidy level had a significant effect on pollen staining $(\mathrm{F}$ value $=274.9, P<0.0001)$ and germination $(\mathrm{F}$ value $=136.3, P<0.0001)$. Diploid $(2 x)$ and tetraploid $(4 x)$ plants had greater pollen staining (96.8\% and $94.1 \%$, respectively) and germination ( $89.1 \%$ and $76.3 \%$, respectively) than triploids $(3 x)$ (40.6\% staining and $5.9 \%$ germination).

Crosses between diploids $(2 x)$ resulted in $64.0 \%$ fruit set with an average of 632 seeds per fruit and a germination percentage of $26.3 \%$ (Table 3 ). Only two fruit formed in $2 x \times 3 x$ crosses, with an average of 138 seeds per fruit which germinated at $1.0 \%$. Crosses between $2 x \times 4 x$ were not successful. Triploids failed to set fruit and viable seeds when pollinated with $2 x$ or $3 x$ pollen. One fruit was collected from $3 x \times 4 x$ crosses, yielding four seeds which failed to germinate. Tetraploids were successfully crossed with $2 x$ and $4 x$ pollen, resulting in similar percentage fruit sets, average seeds per fruits and seed germination values. Crosses between $4 x \times 3 x$ were unsuccessful. Germination was erratic for diploid $(2 x \times 2 x)$, triploid $(4 x \times 2 x)$ and tetraploid $(4 x \times 4 x)$ seed, as evident in the very broad least significant difference $\left(\operatorname{LSD}_{0.05}\right)$ for seed germination $(28.4 \%)$.

\section{Discussion}

Reciprocal di-hybrid crosses were performed to rule out maternal effects on inheritance of each trait, in particular, variegation. Variegated foliage is often the result of abnormal plastid development due to mutations in chloroplast genes and can result in strict maternal inheritance or non-Mendelian inheritance due to stochastic sorting of aberrant vs. normal plastids during cell division and transmission to germ cells (Tilney-Bassett, 1978; Walbot and Coe, 1979). $F_{1}$ reciprocal crosses of $G \times$ AP resulted in non-variegated, green progeny (wild-type), indicating that

Table 3. Fertility as a function of ploidy in Hypericum androsaemum reciprocal interploid crosses.

\begin{tabular}{|c|c|c|c|c|c|}
\hline \multirow{2}{*}{$\begin{array}{l}\text { Female } \\
\text { parent }\end{array}$} & \multirow{2}{*}{$\begin{array}{l}\text { Male } \\
\text { parent }\end{array}$} & \multicolumn{3}{|c|}{ Fruit developed } & \multirow{2}{*}{$\begin{array}{c}\text { Seed } \\
\text { germination } \\
(\%)^{y}\end{array}$} \\
\hline & & (no.) & $(\%)^{\mathrm{z}}$ & $\overline{(\text { avg no. seeds) }}$ & \\
\hline $2 x$ & $2 x$ & 32 & $64.0 \mathrm{a}^{\mathrm{x}}$ & $632 \mathrm{a}$ & $26.3 \mathrm{a}$ \\
\hline $2 x$ & $3 x$ & 2 & $2.0 \mathrm{~b}$ & $138 \mathrm{ab}$ & $1.0 \mathrm{a}$ \\
\hline $2 x$ & $4 x$ & 0 & 0.0 & --- & --- \\
\hline $3 x$ & $2 x$ & 0 & 0.0 & --- & --- \\
\hline $3 x$ & $3 x$ & 0 & 0.0 & --- & --- \\
\hline $3 x$ & $4 x$ & 1 & $4.2 \mathrm{~b}$ & $4.0 \mathrm{~b}$ & $0.0 \mathrm{a}$ \\
\hline $4 x$ & $2 x$ & 7 & $10.8 \mathrm{~b}$ & $260 \mathrm{ab}$ & $5.7 \mathrm{a}$ \\
\hline $4 x$ & $3 x$ & 0 & 0.0 & --- & --- \\
\hline $4 x$ & $4 x$ & 15 & $20.7 \mathrm{~b}$ & $264 a b$ & $8.4 \mathrm{a}$ \\
\hline $\mathrm{LSD}_{0.05}$ & & & 23.7 & 567 & 28.4 \\
\hline
\end{tabular}

zMeans for single-plant replicates $(\mathrm{n}=5)$ with 10 subsamples (flowers pollinated) per replicate, except $3 x \times 3 x(n=3)$ and $4 x \times 4 x(n=4)$. $\mathrm{y}_{\mathrm{n}}=$ total number of fruit harvested per cross.

xMeans followed by the same letter, within a column, not significantly different based on Fisher's protected LSD at $\alpha=0.05$. variegation in H. androsaemum f. variegatum 'Glacier' is not the result of maternally (or paternally) transmitted aberrant plastids. Recovery of variegated progeny in $\mathrm{F}_{2} \mathrm{~s}$ at the expected 9:3:3:1 segregation ratio and in $\mathrm{BCP} 1$ at $1: 1$ is evidence that variegation is controlled by a monogenic, recessive nuclear gene. We propose the gene symbol var (variegated) for the recessive allele producing the variegated phenotype (var/var) of $H$. androsaemum f. variegatum and the cultivars Mrs. Gladis Brabazon and Glacier derived from this forma. Presence of variegation only in homozygous genotypes, with no aberrant plastid transmission, suggests the variegated allele is a mutation at a locus that regulates chloroplast gene expression or encodes a protein necessary for proper functioning of the chloroplast. Plastid restitution occurs when at least one wild-type allele is present, as in the immutans mutant of Arabidopsis thaliana (L.) Heynh. (Aluru and Rodermel, 2004).

The lack of purple foliage in $\mathrm{F}_{1} \mathrm{~s}$ and recovery of purple progeny at the expected ratio in the $\mathrm{F}_{2} \mathrm{~s}$ supports our hypothesis of simple recessive inheritance for purple foliage. We propose the gene symbol $p l$ (purple leaf) for the recessive allele originating from H. androsaemum 'Albury Purple.' Purple (or red) foliage variants, resulting from foliar accumulation of anthocyanins, have variously been described in agronomic crops and are important in ornamental plant breeding programs. Cadic (1992) reported inheritance of purple foliage in barberries (Berberis L.) due to a single recessive gene, as we observed in $H$. androsaemum. In peach [Prunus persica (L.) Batsch.] red foliage is controlled by a single locus, $G r$, and with the $G r$ allele incompletely dominant (Chaparro et al., 1995), as is bronze-leaf (Rt) in Malus Mill. (Alston et al., 2000; Sampson and Cameron, 1965). The lack of purple pigmentation in our $\mathrm{F}_{1} \mathrm{~s}$ and no variation in purple foliage intensity in our segregating progeny suggests totally recessive gene action. In other woody plant genera, inheritance of purple foliage is dominant as in Betula pendula Roth. 'Purpurea' (Hattemer et al., 1990), Fagus sylvatica L. (Blinkenberg et al., 1958; Heinze and Geburek, 1995), and Corylus L. (Smith and Mehlenbacher, 1996; Thompson, 1985), though variation in coloration exists in Corylus due to different alleles and complimentary gene action. Backcrossing to $\mathrm{AP}(\mathrm{BCP} 2)$ resulted in the recovery of more purple seedlings than expected; however, these may be explained by accidental self-pollination. Recovery of a few spontaneous variegated progeny was not expected in $\mathrm{BCP} 2$, and not explained by selfing or pollen contamination. Phenotypes were scored at the three-leaf stage, and these seedlings may represent the accumulation of deleterious alleles unrelated to the variegated locus or instability of our variegated locus due to a transposable element.

Recovery in $\mathrm{F}_{2}$ lines of individuals with both variegated and purple foliage at the expected ratio indicates that the two traits (loci) are not closely linked. Based on a simple recessive model of inheritance for both variegated and purple foliage, phenotypes displaying the novel combination of variegation on purple foliage have the genotype $\mathrm{var} / \mathrm{var} \mathrm{pl} / \mathrm{pl}$.

Both traits behaved as expected at the triploid level, but at the tetraploid level we recovered more variegated, green progeny than expected. At the tetraploid level, segregation ratios for the variegated trait fell between that expected with random chromosome assortment and random chromatid assortment for autotetraploids. Assuming random pairing between homologous chromosomes and independent assortment, we would expect perfect tetrasomic inheritance and 35 non-variegated: 1 variegated progeny in the $\mathrm{F}_{2(4 x)}$. However, the prevalence of multivalent formation and frequency of recombination will influence double reduction and 
affect segregation ratios in autotetraploids (Allard, 1960; Ramsey and Schemske, 2002). Random chromatid assortment predicts that crossing-over occurs between the locus and the centromere in tetraploids, which allows for double reduction (sister chromatids in the same gamete). Thus, if we assume random chromatid assortment (quadrivalents with at least one chiasma) we would expect 20.8 non-variegated: 1 variegated progeny in the $\mathrm{F}_{2(4 x)}$. Our observed ratio was $\sim 10$ non-variegated: 1 variegated, falling between the two models. Assuming preferential pairing is limited in recently induced autotetraploids (Wu et al., 2001); the frequency of double reduction would then have a larger impact on allele frequencies and gametic genotypes (Ramsey and Schemske, 2002). In our induced tetraploid $\mathrm{F}_{2(4 x)} \mathrm{s}$, double reduction would increase the production of homozygous gametes and thus increase the number of nulliplexes (homozygous recessive with four alleles) and the number of variegated progeny. Double reduction depends on the location of a locus on a chromosome relative to the centromere and the rate of chiasma formation, thus double reduction rates will vary among loci. This may explain the increased recovery of variegated progeny and the unaffected frequency of purple progeny if the purple locus is located closer to the centromere. In autotetraploid easter cactus (Hatiora $\times$ graeseri Barthlott ex D. Hunt) isozyme segregation ratios fit random chromosomal or chromatidal assortment, depending on the specific loci (Karle et al., 2002), and in allotetraploid quinoa (Chenopodium quinoa Willd) discrepancies in tetrasomic segregation ratios for the $R$ locus controlling inflorescence color were attributed to variable multivalent formation (Ward, 2000).

Inducing tetraploidy apparently had little effect on male fertility, with pollen staining similar to diploids, however pollen germination slightly decreased compared to that of the diploid. Female fertility, measured as percentage fruit set, was lower in the tetraploids when selfed or crossed with diploids than for diploid selfs. In reciprocal crosses between diploid and tetraploid inbred lines of Salpiglossis sinuata R. \& P., fruit set did not differ between crosses, however, the number of seeds produced was significantly lower in selfed tetraploids (Needham and Erickson, 1992). For autotetraploids reductions in pollen and seed fertility are usually reduced compared to their diploid progenitor (Ramsey and Schemske, 2002) which is often attributed to the production of multivalents, the frequency of which is negatively correlated with fertility (Sybenga, 1996). In our study, tetraploid selfs had lower percentage fruit set, but average seeds set per fruit and percentage seed germination were not significantly different.

Diploid $H$. androsaemum pollinated with tetraploid pollen $(2 x \times 4 x)$ failed to set fruit. Crosses in this direction commonly fail and violate the endosperm balance number theory, which predicts embryo abortion for crosses that violate a 2 maternal : 1 paternal genomic ratio in developing endosperm (Carputo et al., 1999; Johnston et al., 1980; Sanford, 1983). Crosses with tetraploid $H$. androsaemum as the female $(4 x \times 2 x)$ were successful in producing triploids.

Triploids are expected to be highly infertile owing to uneven segregation from increased multivalent formation and partner exchange during meiosis (Sybenga, 1996) leading to abortive gamete development. Triploids had low pollen germination, even though pollen staining was $40.6 \%$. Pollen staining often results in an overestimation of pollen viability (Olsen et al., 2006) with germination and successful pollination more indicative of viability. Triploid pollen failed to initiate fruit set in selfs and in crosses with tetraploid females in the current study. An additional 139 triploid flowers were selfed on various triploid plants after the study, resulting in a total of five fruit averaging 41.8 seeds per fruit (data not shown). Diploids pollinated with triploid pollen resulted in just two fruit with reduced seed set and low germination (1\%), which may have been the result of diploid pollen contamination or selfing. One fruit was initiated on $3 x \times 4 x$ crosses, which contained four seeds that failed to germinate. We were unable to recover any viable seeds from triploid female parents regardless of the ploidy level of the male parent. The fertility of triploids are dependent on the production of euploid gametes $(n=x, 2 x$, or $3 x$ ) or tolerance of gametes and zygotes to aneuploidy. Triploid blueberries (Vaccinium corymbosum L.) are highly sterile, though crosses with tetraploids and hexaploids are variably successful due to the production of $2 n$ gametes and tolerance of aneuploid gametes above $2 x$ level (Vorsa and Ballington, 1991). Triploid bananas are regarded as sterile, although Ortiz and Vuylsteke (1995) were able to identify clones with residual fertility due to production of euploid gametes from selective elimination of one chromosome set during meiosis. The identification of fertile triploids are valuable for breeding programs; however, selecting infertile triploids are just as valuable for limiting the unwanted spread of ornamental plants in the landscape. The above studies in blueberries and bananas, as well as triploid Lathyrus pratensis L. (Khawaja et al., 1997), S. sinuata (Needham and Erickson, 1992) and our triploid $H$. androsaemum suggest that hybrid triploids can be screened for infertility as a viable approach for developing new non-invasive cultivars.

Variegated (var) and purple $(p l)$ foliage in $H$. androsaemum are both simple recessive traits and are not linked, allowing the recovery of the two parental phenotypes as well as the novel combined phenotype (var/var pl/pl) at the triploid and tetraploid levels. The greatly reduced male fertility and apparent lack of female fertility among triploids should allow for selection of novel, non-invasive $H$. androsaemum cultivars.

\section{Literature Cited}

Allard, R.W. 1960. Principles of plant breeding. Wiley, New York.

Alston, F.H., K.L. Phillips, and K.M. Evans. 2000. A Malus gene list. Acta Hort. 538:561-570.

Aluru, M.R. and S.R. Rodermel. 2004. Control of chloroplast redox by the IMMUTANS terminal oxidase. Physiol. Plant. 120:4-11.

Blinkenberg, C., H. Brix, M. Schaffalitzky de Muckadell, and H. Vedel. 1958. Controlled pollinations in Fagus. Silvae Genetica 9:116-122.

Cadic, A. 1992. Breeding for ever-red barberries (Berberis spp.). Acta Hort. 320:85-90.

Carputo, D., L. Monti, J.E. Werner, and L. Frusciante. 1999. Uses and usefulness of endosperm balance number. Theor. Appl. Genet. 98:478-484

Chaparro, J.X., D.J. Werner, R.W. Whetten, and D.M. O’Malley. 1995. Inheritance, genetic interaction, and biochemical characterization of anthocyanin phenotypes in peach. J. Hered. 86:32-38.

Dias, A.C.P., R.M. Seabra, P.B. Andrade, F. Ferreres, and M. Fernandes-Ferreira. 2000. Xanthone biosynthesis and accumulation in calli and suspended cells of Hypericum androsaemum. Plant Sci. 150:93-101.

Egolf, D.R. 1970. Hibiscus syriacus 'Diana', a new cultivar [Malvaceae]. Baileya 17:75-78.

Egolf, D.R. 1981. 'Helene' rose of sharon (althea). HortScience 16:226-227.

Egolf, D.R. 1986. 'Minerva' rose of sharon (althea). HortScience 21:1463-1464.

Egolf, D.R. 1988. 'Aphrodite' rose of sharon (althea). HortScience 23:223.

Gustafsson, M.H.G., V. Bittrich, and P.F. Stevens. 2002. Phylogeny of Clusiaceae based on $r b c L$ sequences. Intl. J. Plant Sci. 163:1045-1054. 
Hattemer, H.H., W. Steiner, and D. Kownatzki. 1990. Genetic markers in birch. Silvae Genetica 39:45-50.

Heinze, B. and T. Geburek. 1995. Searching for DNA markers linked to leaf colour in copper beech Fagus sylvatica L. var. atropunicea. Silvae Genetica 44:339-343.

Johnston, S.A., T.P.M. den Nijs, S.J. Peloquin, and R.E. Hanneman, Jr. 1980. The significance of genic balance to endosperm development in interspecific crosses. Theor. Appl. Genet. 57:5-9.

Karle, R., C.A. Parks, M.C. O'Leary, and T.H. Boyle. 2002. Polyploidyinduced changes in the breeding behavior of Hatiora $\times$ graeseri (Cactaceae). J. Amer. Soc. Hort. Sci. 127:397-403.

Khawaja, H.I.T., J. Sybenga, and J.R. Ellis. 1997. Chromosome pairing and chiasma formation in autopolyploids of different Lathyrus species. Genome 40:937-944.

Kihara, H. 1951. Triploid watermelons. Proc. Amer. Soc. Hort. Sci. 58:217-230.

Kirakosyan, A., T.M. Sirvent, D.M. Gibson, and P.B. Kaufman. 2004. The production of hypericins and hyperforin by in vitro cultures of st. john's wort (Hypericum perforatum). Biotechnol. Appl. Biochem. 39:71-81.

Mabberley, D.J. 1997. The plant book. Cambridge Univ. Press, Cambridge, U.K.

Marquard, R.D. 1992. Pollen tube growth in Carya and temporal influence of pollen deposition on fertilization success in pecan. J. Amer. Soc. Hort. Sci. 117:328-331.

Matzk, F., A. Meister, and I. Schubert. 2000. An efficient screen for reproductive pathways using mature seeds of monocots and dicots. Plant J. 21:97-108.

McClintock, D., E.C. Nelson, and J. Cassells. 1986. Variegated tutsan, Hypericum androsaemum f. variegatum. J. Irish Garden Plant Soc. 5:25-28.

McLaren, D.A., E. Bruzzese, and I.G. Pascoe. 1997. The potential fungal pathogens to control Hypericum species in Australia. Plant Protection Qrtly. 12:81-83.

Needham, D.C. and H.T. Erickson. 1992. Fecundity of tetraploid x diploid crosses and fertility of the resultant triploids in Salpiglossis sinuata. HortScience 27:835-837.

Olsen, R.T, T.G. Ranney, and Z. Viloria. 2006. Reproductive behavior of induced allotetraploid $\times$ Chitalpa and in vitro embryo culture of polyploid progeny. J. Amer. Soc. Hort. Sci. 131:716-724.

Ortiz, R. and D. Vuylsteke. 1995. Factors influencing seed set in triploid Musa spp. L. and production of euploid hybrids. Ann. Bot. 75:151-155.
Ramsey, J. and D.W. Schemske. 2002. Neopolyploidy in flowering plants. Annu. Rev. Ecol. Systematics 33:589-639.

Ranney, T.G. 2004. Population control: Developing non-invasive nursery crops. Combined Proc. Intl. Plant Propagators' Soc. 54:604-607.

Reichard, S.H. and P. White. 2001. Horticulture as a pathway of invasive plant introductions in the United States. BioScience 51:103-113.

Robson, N.K.B. 1985. Studies in the genus Hypericum L. (Guttiferae). 3. Sections 1. Campylosporus to 6a. Umbraculoides. Bul. Brit. Museum (Natural History) Bot. Ser. 12:163-325.

Sampson, D.R. and D.F. Cameron. 1965. Inheritance of bronze foliage, extra petals and pendulous habit in ornamental crabapples. Proc. Amer. Soc. Hort. Sci. 86:717-722.

Sanford, J.C. 1983. Ploidy manipulations, p. 100-123. In: J.N. Moore and J. Janick (eds.). Methods in fruit breeding. Purdue Univ. Press, West Lafayette, Ind.

Smith, D.C. and S.A. Mehlenbacher. 1996. Inheritance of contorted growth in hazelnut. Euphytica 89:211-213.

Sybenga, J. 1996. Chromosome pairing affinity and quadrivalent formation in polyploids: Do segmental allopolyploids exist? Genome 39:1176-1184.

Thompson, M.M. 1985. Linkage of the incompatibility locus and red pigmentation genes in hazelnut. J. Hered. 76:119-122.

Tilney-Bassett, R.A.E. 1978. Plastids and variegation: Stable pattern genes, p. 253-285. In: J.T.O. Kirk and R.A.E. Tilney-Bassett (eds.). The plastids: Their chemistry, structure, growth and inheritance. Elsevier, New York.

Valentão, P., E. Fernandes, F. Carvalho, P.B. Andrade, R.M. Seabra, and M.d.L. Bastos. 2002. Antioxidant activity of Hypericum androsaemum infusion: Scavenging activity against superoxide radical, hydroxyl radical and hypochlorous acid. Biol. Pharmaceutical Bul. (Tokyo) 25:1320-1323.

Vorsa, N. and J.R. Ballington. 1991. Fertility of triploid highbush blueberry. J. Amer. Soc. Hort. Sci. 116:336-341.

Walbot, V. and E.H. Coe, Jr. 1979. Nuclear gene iojap conditions a programmed change to ribosome-less plastids in Zea mays. Proc. Natl. Acad. Sci. USA 76:2760-2764.

Ward, S.M. 2000. Allotetraploid segregation for single-gene morphological characters in quinoa (Chenopodium quinoa Willd.). Euphytica 116:11-16.

Wu, R., M. Gallo-Meagher, R.C. Littell, and Z.-B. Zeng. 2001. A general polyploid model for analyzing gene segregation in outcrossing tetraploid species. Genetics 159:869-882. 